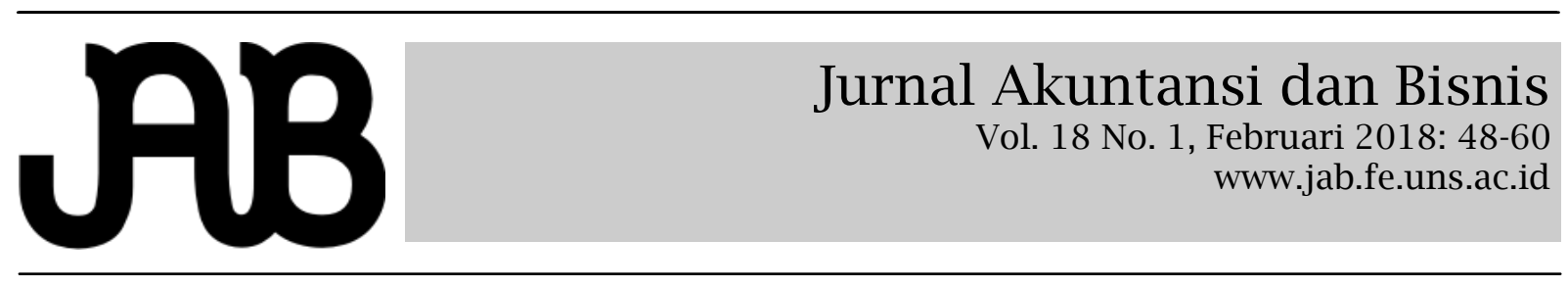

\title{
PENGARUH CORPORATE SOCIAL RESPONSIBILITY TERHADAP PERENCANAAN AGRESIVITAS PAJAK
}

FARIDATUL MAKHFUDLOH (faridatulmakhfudloh645@gmail.com)

NURUL HERAWATI (herawati@trunojoyo.ac.id)

ANIS WULANDARI (aniswulandari1705@gmail.com)

Program Studi Akuntansi, Fakultas Ekonomi dan Bisnis, Universitas Trunojoyo Madura, Indonesia

\begin{abstract}
A B S T R A C T
This study examine the empirical association between corporate social responsibility (CSR) and aggressive tax planning. The dependent variable is used in this study is aggressive tax planning that measured using ETR (effective tax rates). The independent variable in this study is corporate social responsibility. While control variable in this study is leverage, liquidity, profitability, company size, capital intensity, and inventory intensity. This study use 55 sample (firm-years) that listed on the Jakarta Islamic Index that listed on the Indonesia Stock Exchange in the period 2010-2014. Data were analyzed using multiple linier regression analysis model. The result show that did not effect that significant between CSR to aggressive tax planning.

Keywords : Corporate Social Responsibility, Aggressive Tax Planning, Effective Tax Rates

Penelitian ini bertujuan untuk memberikan bukti empiris mengenai pengaruh Corporate Social Responsibility terhadap perencanaan agresivitas pajak. Variabel dependen yang digunakan dalam penelitian ini adalah perencanaan agresivitas pajak yang diukur dengan menggunakan ETR (Effective Tax Rates). Variabel independen dalam penelitian ini adalah CSR (Corporate Social Responsibility). Sedangkan variabel kontrol dalam penelitian ini adalah leverage, likuiditas, profitabilitas, ukuran perusahaan, intensitas modal, dan intensitas persediaan. Penelitian ini menggunakan 55 sampel perusahaan yang terdaftar dalam JII (Jakarta Islamic Index) yang terdaftar di Bursa Efek Indonesia periode tahun 2010-2014. Data analisis menggunakan model analisis regresi linier berganda. Hasil penelitian ini menunjukkan bahwa tidak terdapat pengaruh yang signifikan antara CSR terhadap perencanaan agresivitas pajak.

Kata kunci : Corporate Social Responsibility, Perencanaan Agresivitas Pajak, Effective Tax Rates
\end{abstract}

\section{PENDAHULUAN}

Pajak merupakan faktor yang memotivasi beberapa pengambilan keputusan perusahaan (Lanis \& Richardson, 2012). Hal itu terjadi karena pajak adalah salah satu biaya bisnis paling signifikan yang dikeluarkan oleh perusahaan, dan itu memiliki dampak langsung pada profitabilitas dan nilai pemegang saham (Landry et al., 2013). Akibatnya, perusahaan memiliki insentif keuangan untuk menjadi agresif pajak (Chen et al., 2010). Namun, perilaku agresif pajak dapat berdampak buruk terhadap reputasi perusahaan, aset yang tak ternilai.

Perusahaan-sebagai Wajib Pajak
Badan-memiliki kewajiban membayar pajak. Di sisi lain, perusahaan juga memiliki kewajiban melaksanakan kegiatan Corporate Social Responsibility (selanjutnya disingkat menjadi CSR) sebagai tindak lanjut tanggung jawab sosial kepada masyarakat. Perusahaan terus berusaha memastikan bahwa mereka beroperasi dalam batas dan norma masyarakat (Deegan, Rankin \& Tobin, 2002). Dalam konteks ini, Bowman \& Haire (1976: 13) mendefinisikan tanggung jawab sosial perusahaan (CSR) secara luas sebagai "termasuk kepedulian terhadap dampak semua aktivitas perusahaan terhadap kesejahteraan masyarakat." Deegan, Rankin dan Tobin 
(2002) menyatakan bahwa pengungkapan CSR dipandang sebagai sarana yang digunakan oleh menajemen perusahaan dalam berinteraksi dengan masyarakat yang lebih luas untuk mempengaruhi presepi. Lanis dan Richardson (2012) menyatakan bahwa CSR merupakan faktor kunci dalam keberhasilan dan kelangsungan hidup perusahaan.

Di Indonesia, peraturan mengenai pemberian CSR yang dilakukan oleh perusahaan diatur dalam Undang-Undang Perseroan Terbatas No. 40 Tahun 2007 pasal 1 ayat 3 yang menyatakan bahwa tanggung jawab sosial dan lingkungan adalah komitmen perseroan untuk berperan serta dalam pembangunan ekonomi berkelanjutan guna meningkat-kan kualitas kehidupan dan lingkungan yang bermanfaat, baik bagi perseroan sendiri, komunitas setempat. Peraturan Pemerintah No. 47 Tahun 2012 pasal 3 juga mengatur tanggung jawab sosial dan lingkungan perseroan terbatas, yang menyatakan bahwa tanggung jawab sosial dan lingkungan sebagaimana dimaksud dalam pasal 2 menjadi kewajiban bagi perseroan yang menjalankan kegiatan usahanya di bidang dan/ atau berkaitan dengan sumber daya alam berdasarkan undang-undang. Dalam pemberian CSR yang dilakukan oleh suatu perusahaan memang perusahaan akan beranggapan bahwa CSR merupakan beban yang harus dikeluarkan oleh perusahaan, padahal sebenarnya CSR merupakan suatu bentuk timbal balik perusahaan kepada masyarakat dalam hal tanggung jawab sosial terhadap masyarakat, sedangkan ekspektasi yang diharapkan oleh sebagian besar masyarakat tidak sesuai dengan CSR yang diungkapkan oleh perusahaan (Oktaviana, 2014).

Strategi pelaporan CSR dan perilaku pajak adalah keputusan perusahaan. Keduanya sering dianggap sebagai beban bagi perusahaan. Perusahaan akan berusaha mencari strategi keputusan perusahaan untuk meminimalkan beban perusahaan. Praktik perencanaan agresivitas pajak sering dilakukan oleh perusahaan. Entah itu perencanaan agresivitas pajak yang dilakukan secara legal ataupun perencanaan agresivitas pajak yang dilakukan secara ilegal (Frank, Lynch \& Rego, 2009). Harari et al. (2013) menyatakan bahwa praktik perencanaan agresivitas pajak dapat merusak kemampuan masyarakat, merugikan kesetaraan sosial dan pelaksanaan kebijakan sosial atau ekonomi dengan cara sistem pajak, dan memaksakan beban ekonomi pada masyarakat yang tidak atau tidak dapat melakukan perencanaan agresivitas pajak tersebut. Tindakan perencanaaan agresi-vitas ini dianggap tidak etis dan tidak sah, bahkan jika itu benar-benar berbicara dalam lingkup sesuai dengan aturan hukum. Pandangan masyarakat mengenai perusahaan yang melakukan tindakan agresivitas dianggap menjadi-kan perusahaan telah melakukan suatu tindakan atau kegiatan yang tidak bertanggung jawab secara sosial dan tidak sah telah membentuk suatu kegiatan yang tidak bertanggung jawab secara sosial dan tidak sah (Lanis \& Richardson, 2013). Diperlukan suatu tindakan oleh perusahaan untuk mem-buat citra perusahaan semakin baik dengan memberikan peningkatan kualitas perusahaan, masyarakat, khususnya komunitas sekitar, serta lingkungan hidup. Hal ini dapat dilakukan perusahaan dengan melakukan kegiatan CSR sebagai bentuk rasa tanggung jawab sosial perusahaan terhadap masyarakat sekitar.

Beberapa penelitian telah mengeksplorasi hubungan antara praktik pelaporan CSR dan pajak. Studi sebelumnya menyajikan hasil yang beragam pada asosiasi antara CSR dan tingkat perencanaan pajak. Davis et al. (2016), Zeng (2016), Lanis dan Richardson (2015), dan Huseynov dan Klamm (2012) menemukan bahwa perusahaan yang bertanggung jawab secara sosial melakukan lebih sedikit kegiatan perencanaan pajak agresif (penghindaran pajak) dibandingkan dengan perusahaan yang tidak bertanggung jawab secara sosial. Di sisi lain, Watson (2011) menemukan bahwa perusahaan dengan kinerja CSR yang tinggi menunjukkan aktivitas perencanaan pajak tingkat tinggi. Begitu juga Hoi, Wu dan Zhang (2013) dan Watson (2015) memberikan bukti bahwa perusahaan 
dengan aktivitas CSR yang tidak bertanggung jawab secara berlebihan memiliki kecenderungan lebih tinggi untuk melibatkan kebijakan penghindaran pajak yang sangat agresif. Lanis dan Richardson (2012) menemukan perusahaan agresif pajak akan mengungkapkan sejumlah besar informasi CSR daripada perusahaan agresif non-pajak.

Penelitian hubungan antara pajak dan tanggung jawab sosial perusahaan yang ada di atas menggunakan setting bisnis di negara-negara Barat (common law). Davis et al. (2016), Watson (2015), Lanis dan Richardson (2015), Hoi Wu dan Zhang (2013), Huseynov dan Klamm (2012), dan Watson (2011) menggunakan sampel perusahaan publik di Amerika Serikat. Zeng (2016) dan Landry, Deslandes dan Fortin (2013) menggunakan setting perusahaan publik di Kanada dan Lanis dan Richardson (2012) perusahaan di Australia.

Penelitian ini bertujuan untuk menguji kembali pengaruh CSR terhadap perencanaan agresivitas pajak suatu perusahaan dengan setting Indonesia. Indonesia merupakan negara yang masuk dalam kluster negara-negara code law dengan karakteristik (Leuz, Nanda \& Wysocki, 2003; Tang, 2015; Tsakumis, Curatola \& Porcano, 2007; Djankov et al., 2008) antara lain: (a) tingkat perlindungan investor yang lemah, (b) kepemilikian terkonsentrasi, (c) sumber pendanaan utama perusahaan dari bank, (d) tingkat manajemen laba yang tinggi, dan (e) tingkat penghindaran/penggelapan pajak yang tinggi. Perbedaan konteks institusional Indonesia ini memungkinkan hasil yang berbeda dengan penelitian sebelumnya di negara Barat. Penelitian tentang hubungan antara pajak dan tanggung jawab sosial perusahaan telah banyak dilakukan di Indonesia. Penelitian yang telah ada (seperti Harjito, Sari \& Yulianto, 2017; Yunistiyani \& Tahar, 2017; Sari, Darlis \& Wiguna 2017; Mumtahanah \& Septiani, 2017; Kusumo \& Asyik, 2017; Damayanti, 2017; Tjondro, Widuri \& Katopo, 2016; Wahyudi, 2016; Kuriah \& Asyik, 2016; Prasista \& Setiawan, 2016; Maraya \& Yendrawati, 2016; Hidayat, Ompusunggu \&
Suranto, 2016; Napitu \& Kurniawan, 2016; Purwanggono \& Rohman, 2015; Sagala \& Ratmono, 2015; Muzakki \& Darsono, 2015; Rini, Handajani \& Sasanti, 2015; Pradipta \& Supriyadi, 2015; Pradnyadari \& Rohman, 2015; Nusantari, Nuzula dan Darono, 2015; Anita, Basri dan Julita, 2015; Warsono \& Ardianto, 2015) menggunakan sampel penelitian dari perusahaan yang terdaftar di Bursa Efek Indonesia (BEI). Gunawan (2017) menggunakan sampel semua perusahaan di Indonesia yang menyajikan laporan keberlanjutan tahun 2014 yang daftar perusahaannya diperoleh dari situs National Center for Sustainability Reporting. Penelitian ini menggunakan sampel perusahaan go public yang terdaftar dalam Jakarta Islamic Index (selanjutnya disingkat menjadi JII) perioda 2010-2014. Alasan penggunaan sampel ini adalah perusahaan yang tercatat dalam JII mempunyai kewajiban untuk menyampaikan laporan keuangan dan laporan tahunan perusahaan kepada pihak luar perusahaan, terutama pada stakeholder, melainkan juga sudah mencantumkan CSR dalam laporan tahunan perusahaan. Selain itu, sahamsahamnya telah dianggap memenuhi kriteria syariah. JII terdiri dari perusahaanperusahaan yang bonafit dengan seleksi yang begitu ketat dan sebagian besar mempunyai profitabilitas yang tinggi maka perusahaan dalam JII tersebut harusnya melakukan pengungkapan pertanggungjawaban sosial dalam pelaporan keuangannya secara transparan.

\section{T IN JA UA N P US T AKA DAN PENGEMBANGAN HIPOTESIS}

Teori legitimasi menjelaskan perusaha-an melakukan kegiataan usaha dengan batasan-batasan yang ditentukan oleh norma-norma, nilai-nilai sosial dan reaksi terhadap batasan tersebut mendorong pentingnya perilaku organisasi dengan memperhatikan lingkungan (Dowling \& Preffer, 1975). Berdasar teori legitimasi tersebut, terdapat dugaan bahwa perusahaan menggunakan pengungkapan CSR dalam rangka menjaga citra (image) di mata masyarakat.

Salah satu tindakan yang dapat dilakukan oleh perusahaan untuk menjaga 
citra (image) perusahaan adalah dengan melakukan pembayaran pajak yang sudah menjadi tanggungannya tanpa adanya praktik perencanaan agresivitas pajak sehingga akan terjalin suatu hubungan dengan pemerintah dengan baik yang nantinya juga ber-pengaruh terhadap pandangan masya-rakat terhadap perusahaan tersebut dengan image yang baik pula. Tindakan perusahaan tersebut didukung pula dengan teori stakeholder yang menjelas-kan tentang pentingnya tanggung jawab sosial perusahaan yang dipengaruhi oleh variabel regulasi pemerintah, tekanan dari masyarakat, tekanan dari organisasi lingkungan, dan tekanan masyarakat media massa, sehingga asumsi dasar dalam hal tanggung jawab sosial perusahaan didasarkan pada teori stakeholder (Maksum \& Kholis, 2003). Stakeholder merupakan pihak yang mempengaruhi atau dapat dipengaruhi oleh perusahaan, baik itu pihak internal, seperti pihak manajemen, ataupun pihak eksternal perusahaan. Sehingga dengan tindakan yang dilakukan oleh perusahaan yakni tidak melakukan tindakan agre-sivitas pajak dan menjalankan kewajiban pembayaran pajaknya dengan baik maka hal tersebut juga akan membina suatu hubungan yang baik pula dengan pihak stakeholder.

Teori signal menjelaskan mengapa perusahaan mempunyai dorongan untuk memberikan informasi laporan keuangan kepada pihak eksternal (Jama'an, 2008). Septiani (2013) menjelaskan bahwa dorongan perusahaan tersebut disebab-kan karena terjadinya asimetri informasi antara pihak manajemen dan pihak eksternal, sehingga untuk mengurangi asimetri informasi maka perusahaan harus mengungkapkan informasi yang dimiliki, baik informasi keuangan maupun non keuangan. Sehingga jika perusahaan taat dalam pembayaran pajaknya maka pihak eksternal akan memerima informasi yang baik pula dari perusahaan tersebut sehingga tidak akan terjadi adanya asimetri informasi dalam suatu perusahaan.

Zeng (2016) menemukan bahwa semakin tinggi peringkat CSR suatu perusahaan, semakin kecil kemungkinan perusahaan untuk melakukan agresivitas perpajakan. Lanis dan Richardson (2015) juga menemukan bahwa semakin tinggi tingkat kinerja CSR sebuah perusahaan, semakin rendah kemungkinan penghindaran pajak. Temuan Lanis dan Richardson (2015) menunjukkan bahwa perusahaan yang lebih bertanggung jawab secara sosial cenderung mengu-rangi penghindaran pajak. Huseynov dan Klamm (2012) menemukan bahwa perusahaan yang bertanggung jawab secara sosial melakukan lebih sedikit kegiatan perencanaan pajak agresif (penghindaran pajak) dibandingkan dengan perusahaan yang tidak bertanggung jawab secara sosial.

Di sisi lain, Watson (2011) menemukan bahwa perusahaan dengan kinerja CSR yang tinggi menunjukkan aktivitas perencanaan pajak tingkat tinggi. Begitu juga, Hoi, Wu dan Zhang (2013) dan Watson (2015) memberikan bukti bahwa perusahaan dengan aktivitas CSR yang tidak bertanggung jawab secara ber-lebihan memiliki kecenderungan lebih tinggi untuk melibatkan kebijakan penghindaran pajak yang sangat agresif. Lanis dan Richardson (2012) juga menemu-kan bukti empiris secara konsisten hubungan positif dan signifikan secara statistik antara agresivitas pajak perusahaan dan pengungkapan CSR. Hal itu dapat disimpulkan bahwa perusahaan agresif pajak akan mengungkapkan sejumlah besar informasi CSR daripada perusahaan agresif non-pajak. Hasil Lanis dan Richardson (2012) ini mengkonfirmasi-kan teori legitimasi dalam konteks agresivitas pajak perusahaan.

Davis et al. (2016) meneliti apakah kedua aktivitas (CSR dan agresivitas pajak) tersebut bertindak sebagai pelengkap (complements) atau pengganti (substitutes) karena teori dan studi empiris yang ada menemukan bukti yang tidak konsisten. Davis et al. (2016) menjelaskan bahwa bagaimana perusaha-an secara bersamasama memilih sejauh mana mereka terlibat dalam CSR dan penghindaran pajak mungkin mencermin-kan bagaimana melibatkan satu aktivitas mempengaruhi biaya dan manfaat pihak lain. Jika 
perusahaan melihat membayar pajak dengan cara yang sama seperti melihat aktivitas CSR, maka kedua kegiatan tersebut bertindak sebagai pelengkap (complements). Dalam hal ini, Davis et al. (2016) mengharapkan adanya hubungan positif antara pembayaran pajak perusahaan dan ukuran CSR. Prediksi ini konsisten dengan teori CSR yang dikembangkan dalam literatur bisnis dan masyarakat yang menunjuk-kan bahwa perusahaan memiliki kewajiban sosial yang melampaui me-maksimalkan kekayaan pemegang saham (Garriga \& Mele, 2004; Mackey, Mackey \& Barney, 2007). Sebaliknya, perusahaan mungkin menganggap membayar pajak sebagai pengurangan dari kesejahteraan sosial karena pembayaran pajak mengurangi inovasi, pertumbuhan lapangan kerja, dan pembangunan ekonomi. Misalnya, Djankov et al. (2008) menemukan 'efek negatif perusahaan yang konsisten dan besar terhadap investasi dan kewira-swastaan.' Jika demikian, maka Davis et al. (2016) menduga pembayaran pajak perusahaan dan CSR untuk bertindak sebagai pengganti (substitutes), dengan hubungan negatif antara kedua ukuran tersebut. Davis et al. (2016) menemukan bukti yang konsisten bahwa tanggung jawab sosial perusahaan terkait secara negatif dengan tingkat pajak efektif lima tahun tunai dan berhubungan positif dengan pengeluaran lobi pajak. Temuan Davis et al. (2016) menunjukkan bahwa, rata-rata, tanggung jawab sosial perusahaan dan pembayaran pajak bertindak sebagai substitusi. Hasil penelitian sebelumnya di atas menunjukkan teori dan hasil penelitian beragam. Oleh karena itu, hipotesis dalam penelitian ini adalah sebagai berikut.

H1: CSR berpengaruh terhadap perencanaan agresivitas pajak.

\section{METODE PENELITIAN}

\section{Populasi dan Sampel}

Populasi dalam penelitian ini adalah perusahaan Go Public yang Terdaftar di Jakarta Islamic Index (JII) perioda 20102014. Alasan penggunaan sampel pada perusahaan yang tercatat di JII karena perusahaan yang tercatat dalam JII mempunyai kewajiban untuk menyampaikan laporan keuangan dan laporan tahunan perusahaan kepada pihak luar perusahaan, terutama pada stakeholder, melainkan juga sudah mencantumkan CSR dalam laporan tahunan perusahaan. Selain itu, saham-sahamnya telah di-anggap memenuhi kriteria syariah.

JII terdiri dari perusahaanperusahaan yang bonafit dengan seleksi yang begitu ketat dan sebagian besar mempunyai profitabilitas yang tinggi maka perusahaan di JII tersebut harusnya melakukan pengungkapan pertanggungjawaban sosial dalam pelaporan keuangannya secara transparan. Sampel penelitian ini dipilih berdasarkan metode purposive sampling. Teknik purposive sampling adalah penentuan teknik sampel dengan pertimbangan tertentu (Sugiyono, 2012: 124). Kriteria dan hasil seleksi pemilihan sampel nampak pada tabel 1 . Sampel final penelitian ini sebanyak 55 (perusahaan-tahun).

\section{Variabel Operasional}

Variabel dependen penelitian ini adalah perencanaan agresivitas pajak. Pengukur perencanaan agresivitas pajak dalam penelitian ini menggunakan proksi ETR (Effective Tax Rate), yang dihitung dengan formula sebagai berikut.

$$
\mathrm{ETR}=\frac{\text { Total Tax Expense }}{\text { Pre tax Income }}
$$

Tabel 1.

Seleksi Sampel

\begin{tabular}{|c|c|c|}
\hline No & Kriteria & Jumlah \\
\hline 1 & $\begin{array}{l}\text { Perusahaan yang } \\
\text { terdaftar dalam JII } \\
\text { perioda 2010-2014 }\end{array}$ & 30 \\
\hline 2 & $\begin{array}{l}\text { Perusahaan yang keluar } \\
\text { masuk dari JII selama } \\
\text { perioda 2010-2014 }\end{array}$ & 18 \\
\hline 3 & $\begin{array}{l}\text { Perusahaan yang tidak } \\
\text { memiliki data secara } \\
\text { lengkap pada laporan } \\
\text { keuangan tahunannva }\end{array}$ & (0) \\
\hline 4 & $\begin{array}{l}\text { Perusahaan yang tidak } \\
\text { menggunakan mata uang } \\
\text { rupiah }\end{array}$ & (1) \\
\hline \multirow[t]{2}{*}{5} & $\begin{array}{l}\text { Data tersedia dan } \\
\text { lengkap-Perusahaan }\end{array}$ & 11 \\
\hline & $\begin{array}{l}\text { Total sampel final } 5 \\
\text { tahun penelitian }\end{array}$ & 55 \\
\hline
\end{tabular}


Variabel independen penelitian ini adalah CSR. Penelitian ini menggunakan check list yang mengacu pada indikator pengungkapan CSR yang digunakan oleh Sembiring (2005) karena lebih sesuai dengan keadaan perusahaan di Indonesia, dimana pengungkapan CSR nya masih bersifat umum dan belum rinci. Indikator pengungkapan tanggung jawab sosial perusahaan (CSR) dalam penelitian ini didasarkan pada 7 kategori, yaitu lingkungan, energi, kesehatan dan keselamatan tenaga kerja, lain-lain tenaga kerja, produk, keterlibatan masyarakat, dan umum. Maka rumus untuk pengukuran pengungkapan CSR yaitu:

$$
\text { CSRIi }=\frac{\sum X y i}{n i}
$$

CSRI adalah Indeks Corporate Social Respon-sibility (ICSR), yi adalah jika item $y$ diungkapkan maka diberi nilai 1 , jika item $y$ tidak diungkapkan diberi nilai 0 , dan ni adalah jumlah item untuk perusahaan (78 item CSR)

Variabel kontrol penelitian ini adalah adalah leverage, likuiditas, profitabilitas, ukuran perusahaan, intensitas modal, dan intensitas persediaan. Leverage dapat didefinisikan sebagai tingkat ketergantungan perusahaan terhadap utang dalam membiayai kegiatan operasi perusahaan (Sembiring, 2005). Dalam penelitian ini leverage dapat dihitung dari (Helfert, 1997: 97) :

$$
\mathrm{LEV}=\frac{\text { Total Utang }}{\text { Total Aset }}
$$

Likuiditas adalah kemampuan perusahaan memenuhi kewajiban jangka pendek. Likuiditas dihitung dari formula berikut ini (Helfert, 1997: 95).

$$
\text { LIQ }=\frac{\text { Aset lancar }}{\text { Utang Lancar }}
$$

Profitabilitas merupakan kemampuan perusahaan dalam mendapatkan laba selama periode tertentu, yang dapat mempengaruhi perusahaan dalam mengungkapkan CSR. Pengukuran ROA (Return On Asset) dalam penelitian ini dengan menggunakan formula berikut ini (Helfert, 1997: 83).
Return on Asset $=\frac{\text { Net Income }}{\text { Total Asset }} \ldots \ldots \ldots \ldots . . .5$

Ukuran suatu perusahaan dapat mempengaruhi luas pengungkapan informasi dalam laporan keuangan mereka. Secara umum perusahaan besar akan mengungkapkan informasi lebih banyak daripada perusahaan kecil (Fahrizqi, 2010). Ukuran perusahaan dapat dihitung dengan formula berikut ini (Heckston \& Milne, 1996).

$$
S I Z E=\log (\text { total asset perusahaan) ........6 }
$$

Intensitas modal diukur dengan membandingkan nilai buku jumlah aset tetap bersih dengan nilai buku total aset perusahaan (Gupta \& Newberry, 1997). Intensitas modal dapat dihitung dengan formula berikut.

$$
\mathrm{CINT}=\frac{\text { Total Aset tetap Bersih }}{\text { Total Aset }}
$$

Intensitas persediaan menggambarkan proporsi persediaan yang dimiliki terhadap total aset perusahaan. Intensitas persediaan dapat dihitung dari formula berikut.

$$
\text { INVT }=\frac{\text { Total Persediaan }}{\text { Total Aset }}
$$

\section{Teknik Analisis Data}

Penelitian ini menggunakan regresi linier berganda yang sebelumnya perlu dilakukan statistik deskriptif, uji asumsi klasik (bebas dari asumsi normalitas, multikolinearitas, heteroskedastisitas, dan autokorelasi) serta uji hipotesis (meliputi koefisien determinasi, uji f, dan uji statistik t).

\section{ANALISIS DAN PEMBAHASAN Statistik Deskriptif}

Deskripsi statistik setiap variabel yang digunakan dalam analisis penelitian ini ditunjukkan pada tabel 2. Perencanaan agresivitas (ETR) menunjukkan nilai ratarata sebesar 0,2305 dengan nilai standar deviasi sebesar 0,03313, nilai minimum sebesar 0,15 dan nilai maksimum sebesar 0,29 . Variabel independen pengungkapan tanggung jawab sosial perusahaan (CSR) menunjukkan nilai rata-rata sebesar 
0,4291. Hal ini menunjukkan bahwa dalam satu perioda dalam annual report, perusahaan telah mengungkapkan 42,91\% dalam annual report mengenai pengungkapan tanggung jawab sosial perusahaan. Pengungkapan CSR terkecil sebesar 0,27, pengungkapan CSR terbesar adalah sebesar 0,59. dan standar deviasi pengungkapan CSR sebesar 0,09354.

Variabel kontrol pertama penelitian ini yaitu leverage (LEV) menunjukkan nilai rata-rata sebesar 0,3491 . Hal ini berarti bahwa perusahaan yang menjadi sampel dalam penelitian ini rata-rata memiliki utang sebesar 34,91\% dari seluruh aset perusahaan. Nilai leverage minimum sebesar 0,13 atau terdapat utang sebesar 13\% dari seluruh aset perusahaan. Nilai leverage terbesar adalah 0,68 dan standar deviasi sebesar 0,16224.

Variabel kontrol kedua yaitu likuiditas (LIQ) menunjukkan nilai rata-rata sebesar 2,6182, dengan nilai minimum sebesar 0,01, nilai maksimum sebesar 6,99 dan standar deviasi 1,80912. Variabel kontrol ketiga yaitu profitabilitas (ROA) menunjukkan nilai rata-rata sebesar 0,1698 . Hal ini berarti perusahaan yang menjadi sampel dalam penelitian ini ratarata mampu meng-hasilkan 16,98\% laba bersih dari total aset yang dimiliki perusahaan. Nilai profita-bilitas minimum diperoleh sebesar 0,04 atau terdapat kerugian mencapai 4\% dari seluruh nilai aset perusahaan. Nilai profitabilitas maksimum adalah sebesar 0,46. Hal ini berarti perusahaan dapat menghasilkan

Tabel 2.

Statistik Deskriptif

\begin{tabular}{lrrrr}
\hline Var & Min & Max & Mean & $\begin{array}{c}\text { Std. } \\
\text { Deviasi }\end{array}$ \\
\hline ETR & 0,15 & 0,29 & 0,2305 & 0,33130 \\
CSR & 0,27 & 0,59 & 0,4291 & 0,09354 \\
LEV & 0,13 & 0,68 & 0,3491 & 0,16224 \\
LIQ & 0,01 & 6,99 & 2,6182 & 1,80912 \\
ROA & 0,04 & 0,46 & 0,1698 & 0,08918 \\
SIZE & 12,75 & 1,37 & 13,3782 & 0,44293 \\
CINT & 0,07 & 0,75 & 0,3609 & 0,19046 \\
INVT & 0,00 & 0,44 & 0,1296 & 0,11579 \\
\hline
\end{tabular}

laba bersih hingga 46\% dari total aset yang dimiliki perusahaan, dan standar deviasi profitabilitas yang dimiliki sebesar 0,08918 .

Variabel kontrol keempat yaitu ukuran perusahaan (SIZE) menunjukkan nilai rata-rata sebesar 13,3782. Nilai minimum menunjukkan sebesar 12,75 dan nilai maksimum sebesar 14,37 dengan standar deviasi sebesar 0,44293. Variabel kontrol kelima yaitu intensitas modal (CINT) menunjukkan rata-rata sebesar 0,3609. Nilai minimum menun-jukkan sebesar 0,07 dan nilai maksimum 0,75 dengan standar deviasi sebesar 0,19046. Variabel kontrol yang terakhir yaitu intensitas persediaan (INVT) menunjukkan rata-rata sebesar 0,1296 . Nilai minimum menunjukkan 0,00 dan nilai maksimum sebesar 0,44 dan standar deviasi sebesar 0,11579 .

\section{Hasil Uji Asumsi Klasik}

Uji asumsi klasik dalam penelitian ini menggunakan uji normalitas, uji multikolinearitas, uji heteroskedastisitas, dan uji autokorelasi. Model analisis yang dibangun terbebas dari masalah uji normalitas, uji multikolinearitas, uji heteroskedastisitas, dan uji autokorelasi seperti yang ditunjukkan dalam tabel 3.

\section{Hasil Uji Koefisien Determinasi}

Hasil uji koefisien determinasi dalam penelitian ini nampak dalam tabel 4. Hasil pengujian koefisien determinasi yang menunjukkan nilai adjusted $R^{2}$ sebesar

Tabel 3.

Hasil Pengujian Asumsi Klasik

\begin{tabular}{ccc}
\hline Uji & $\begin{array}{c}\text { Hasil Model } \\
\text { Regresi }\end{array}$ & Keterangan \\
\hline 1 & Sig $0,850>0,5$ & Terdistribusi normal \\
& Tolerance $>0,1$ & Bebas \\
2 & dan VIF di & Multikolonieritas \\
& bawah 10 & \\
3 & Titik-titik & Tidak ada \\
& menyebar di atas & Heterokedastisitas \\
4 & Signifikansi uji & Tidak ada \\
& Run Test 0,894 & Autokorelasi \\
\hline
\end{tabular}

Tabel 4.

Hasil Uji Koefisien Determinasi

\begin{tabular}{lcccc}
\hline Model & R & $\begin{array}{c}\mathbf{R} \\
\text { Square }\end{array}$ & $\begin{array}{c}\text { Adj. } \mathbf{R} \\
\text { Square }\end{array}$ & SEE \\
\hline 1 & 0,755 & 0,570 & 0,505 & 0,023 \\
\hline
\end{tabular}


0,505. Hal ini berarti bahwa 50,5\% variasi variabel dependen yaitu perencanaan agresivitas pajak yang dihitung dengan ETR yang dapat dijelaskan oleh variasi variabel independen yaitu CSR, leverage, likuiditas, profitabilitas, ukuran perusa-haan, intensitas modal, dan intensitas persediaan dalam penelitian ini. Sedangkan 49,5\% perencanaan agresivitas pajak dapat dijelaskan oleh variabel lain.

\section{Hasil Uji F}

Hasil uji $F$ dalam penelitian ini dapat dilihat dalam tabel 5. Hasil uji F menunjukkan nilai $\mathrm{F}$ sebesar 8,882 dengan nilai signifikansi sebesar 0,000 . Nilai ini signifikan pada tingkat signifikansi 0,05. Uji F mem-berikan hasil yang signifikan. Sehingga dapat disimpulkan bahwa CSR, leverage, likuiditas, profitabilitas, ukuran perusa-haan, intensitas modal, dan intensitas persediaan berpengaruh bersama -sama atau simultan terhadap perencanaan agresivitas pajak.

\section{Hasil Uji t}

Hasil uji t dalam penelitian ini ditunjukkan dalam tabel 6. Hasil uji t menunjukkan bahwa variabel CSR memiliki koefisien regresi positif sebesar 0,059 dengan nilai $t$ hitung 1,530, nilai signifikansi 0,133. Hasil tersebut menunjukkan bahwa tingkat signifikansi $>0,05$, sehingga pengujian hipotesis pertama gagal me-nolak $\mathrm{HO}$. Simpulannya adalah CSR tidak berpengaruh signifikan terhadap tindakan perencanaan agresivitas pajak.

Penelitian ini menggunakan 6 variabel kontrol, yaitu leverage, likuiditas, profitabilitas, ukuran perusahaan, intensitas modal, dan intensitas persediaan. Penjelasan mengenai variabel kontrol adalah sebagai berikut.

Tabel 6 menunjukkan bahwa variabel kontrol leverage (LEV) memiliki koefisien regresi negatif sebesar -0,016 dengan nilai $t$ hitung -0,459, nilai signifikansi sebesar 0,648 . Hasil tersebut menunjuk-kan tingkat signifikansi $>0,05$, sehingga leverage tidak berpengaruh signifikan terhadap tindakan perencanaan agresi-vitas pajak. Likuiditas (LIO) yang merupakan variabel kontrol kedua me-miliki koefisien regresi negatif sebesar -0,005 dengan nilai t hitung -2,204, dan nilai signifikansi 0,032 . Hasil tersebut menunjukkan tingkat signifikansi $<0,05$, sehingga likuiditas berpengaruh signi-fikan negatif terhadap tindakan perencanaan agresivitas pajak.

Profitabilitas (ROA) merupakan variabel kontrol ketiga dan memiliki koefisien regresi negatif sebesar $-0,004$ dengan nilai $t$ hitung $-0,067$, nilai signifikansi 0,947. Hasil tersebut menunjukkan tingkat signifikansi >0,05, sehingga profitabilitas tidak berpengaruh signifikan terhadap tindakan perencana-an agresivitas pajak. Ukuran perusahaan (SIZE) merupakan variabel kontrol keempat memiliki koefisien regresi negatif sebesar -

Tabel 5.

Hasil Uji F

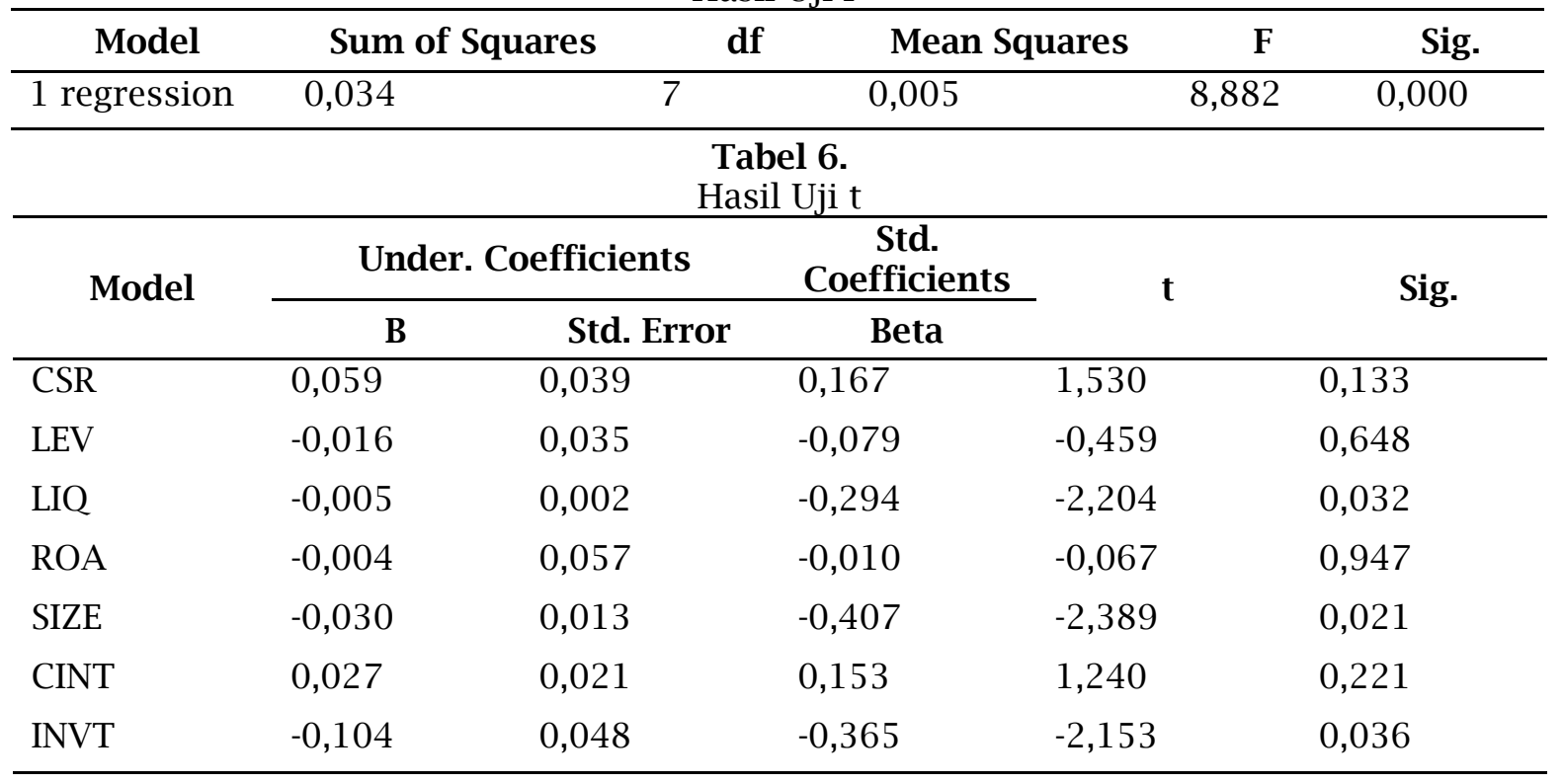


0,030 dengan nilai t hitung $-2,389$, dan nilai signifikansi 0,021. Hasil tersebut menunjukkan tingkat signifikansi $<0,05$, sehingga ukuran perusahaan berpengaruh signifikan negatif terhadap tindakan perencanaan agresivitas pajak.

Intensitas modal (CINT) merupakan variabel kontrol kelima memiliki koefisien regresi positif sebesar 0,027 dengan nilai $\mathrm{t}$ hitung 1,240, dan nilai signifikansi 0,221. Hasil tersebut menunjukkan tingkat signifikansi $>0,05$, sehingga intensitas modal tidak berpengaruh signifikan terhadap tindakan perencanaan agresivitas pajak. Intensitas persediaan (INVT) merupakan variabel kontrol keenam memiliki koefisien regresi negatif sebesar 0,104 dengan nilai t hitung $-2,153$, dan nilai signifikansi 0,036. Hasil tersebut menunjukkan bahwa tingkat signifikansi $<0,05$, sehingga intensitas persediaan berpengaruh signifikan negatif terhadap tindakan perencanaan agresivitas pajak.

\section{Pembahasan}

Penelitian ini memberikan hasil bahwa CSR tidak berpengaruh signifikan terhadap perencanaan agresivitas pajak meski arah hubungan yang ditunjukkan adalah positif. Hasil penelitian ini mendukung temuan Nusantari Nuzula \& Darono (2015), Winarsih, Prasetyono dan Kusufi (2014), Toly dan Jessica (2014), Rohmati (2013) dan Maesarah et al. (2015) yang juga menemukan hasil tidak berpengaruh secara signifikan. Hal ini bisa jadi dikarenakan informasi CSR yang diungkapkan dalam laporan, belum tentu sesuai dengan kondisi sebenarnya. Sehingga tingkat pengungkapan kegiatan tanggung jawab sosial dalam laporan tahunan perusahaan tidak bisa dijadikan jaminan akan rendahnya tindakan pajak agresif yang dilakukan oleh perusahaan (Rohmati, 2013).

Penelitian ini tidak mendukung penelitian yang dilakukan Davis et al. (2016), Zeng (2016), Lanis dan Richardson (2015), Huseynov dan Klamm (2012) dan Pradipta dan Supriyadi (2015) menemukan bahwa perusahaan yang bertanggung jawab secara sosial melakukan lebih sedikit kegiatan perencanaan pajak agresif (penghindaran pajak) dibandingkan dengan perusahaan yang tidak bertanggung jawab secara sosial. Dan juga tidak mendukung temuan Watson (2011), Lanis dan Richardson (2012), Hoi, Wu dan Zhang (2013) dan Watson (2015) yang menemukan bahwa perusa-haan dengan kinerja CSR yang tinggi menunjukkan aktivitas perencanaan pajak tingkat tinggi.

Penelitian ini menggunakan enam variabel kontrol dalam model penelitian, yaitu leverage, likuiditas, profitabilitas, ukuran perusahaan, intensitas modal, dan intensitas persediaan. Terdapat tiga variabel kontrol yang berpengaruh terhadap perencanaan agresivitas pajak, yaitu likuiditas, ukuran perusahaan, dan intensitas persediaan. Sedangkan leverage, profitabilitas, dan intensitas modal tidak berpengaruh terhadap perencanaan agresivitas pajak.

\section{SIMPULAN}

Penelitian ini menemukan bahwa CSR tidak berpengaruh terhadap perencanaan agresivitas pajak. Hasil ini mendukung penelitian sebelumnya yang dilakukan Nusantari, Nuzula \& Darono (2015), Winarsih Prasetyono dan Kusufi (2014), Toly dan Jessica (2014), Rohmati (2013), dan Maesarah, Atikah dan Husnaini (2015). Penelitian ini tidak mendukung penelitian yang dilakukan Davis et al. (2016), Zeng (2016), Lanis dan Richardson (2015), dan Huseynov dan Klamm (2012) menemukan bahwa perusahaan yang bertanggung jawab secara sosial melakukan lebih sedikit kegiatan perencanaan pajak agresif dibandingkan dengan perusahaan yang tidak bertanggung jawab secara sosial. Hasil tersebut juga tidak mendukung temuan Watson (2011), Lanis dan Richardson (2012), Hoi, Wu dan Zhang (2013) dan Watson (2015) yang menemukan bahwa perusahaan dengan kinerja CSR yang tinggi menunjukkan aktivitas peren-canaan pajak tingkat tinggi.

\section{KETERBATASAN DAN SARAN}

Penelitian ini memiliki beberapa keterbatasan penelitian. Pertama, sampel penelitian ini kecil. Hal ini terjadi karena banyak perusahaan yang keluar masuk di 
JII, sehingga banyak mengurangi sampel dalam penelitian. Penelitian selanjutnya dapat menambah sampel yang lebih besar. Kedua, proksi yang digunakan dalam mengukur CSR memiliki unsur subjektivitas dalam menentukan indeks dalam pengungkapan CSR. Hal ini dikarenakan tidak adanya ketentuan baku yang dapat dijadikan acuan sehingga penentuan indeks untuk indikator dalam kategori yang sama dapat berbeda untuk setiap peneliti. Penelitian selanjutnya dapat menggunakan cara pengungkapan CSR yang berbeda, sehingga dapat terjadi keberagaman penelitian. Sebaiknya ada suatu standar baku dalam pengungkapan CSR sehingga subjektivitas peneliti dalam melakukan penelitian dapat diminimal-kan.

\section{DAFTAR PUSTAKA}

Anita, F., Basri, Y.M., \& Julita. (2015). Pengaruh corporate social responsibility, leverage, likuiditas, dan ukuran perusahaan terhadap agresivitas pajak (Studi empiris pada perusahaan real estate dan property yang terdaftar di bursa efek indonesia tahun 2010-2013). Jom FEKON, 2(2), 1 -15 .

Chen, S., Chen, X., Cheng, Q., \& Shevlin, T. (2010). Are family firms more tax aggressive than non-family firms?. Journal of Financial Economics, 95(1), 41-61.

Damayanti, D. (2017). Pengaruh corporate social responsibility (CSR) terhadap agresivitas pajak (studi pada perusahaan manufaktur yang terdaftar di BEI Tahun 2013-2015). Jurnal Ilmiah Cendikia Akuntansi, 5 (2), 43-54.

Davis, A.K., Guenther, D.A., Krull, L.K., \& Williams, B.M. (2016). Do socially responsible firms pay more taxes? The Accounting Review, 91(1), 47-68.

Deegan, C., Rankin, M., \& Tobin, J. (2002). An examination of the corporate social and environmental disclosures of bhp from 1983-1997. Accounting, Auditing \& Accountability, 15(3), 31243.

Djankov, S., La Porta, R., Lopez-de-Silanes, F., \& Shleifer, A. (2008). The law and economics of self-dealing. Journal of Financial Economics, 88, 430-465.

Dowling, J., \& Preffer, J. (1975). Organizational legitimacy. Social Values and Organizational Behavior, 18
(1), 122-136.

Fahrizqi, A. (2010). Faktor-faktor yang mempengaruhi pengungkapan corporate social responsibility (csr) dalam laporan tahunan perusahaan: Studi empiris pada perusahaan manufaktur yang terdaftar dalam bursa efek indonesia (Skripsi). Universitas Diponegoro, Fakultas Ekonomi dan Bisnis, Semarang.

Frank, M.M., Lynch, L.J., \& Rego, S.O. (2009). Tax reporting aggresiveness and its relation to aggressive financial reporting. The Accounting Review, 84 (2), 467-496.

Garriga, E., \& Mele, D. (2004). Corporate social responsibility theories: mapping the territory. Journal of Business Ethics, 53(1/2), 51-71.

Gupta, S., \& Newberry, K. (1997). Determination of the variability in corporate effective tax rates: Evidence from longitudinal data. Journal of Accounting and Public Policy, 1-13

Hackston, D., \& Milne, M.J. (1996). Some determinants of social and environmental disclosure in new zealand companies. Accounting, Auditing and Accountability Journal, 9(1), 77-108.

Harari., Moran., Sitbon, O., \& Kedar, R.D. (2013). Aggressive tax planning and corporate social responsibility in israel. Accountancy Business and the Public Interest, 12, 1-46.

Harjito, Y., Sari, C.N., \& Yulianto. (2017). Tax aggressiveness seen from company characteristics and corporate social responsibility. Journal of Auditing, Finance, and Forensic Accounting, 5(2), 77-91.

Helfert, E.A. (1997). Teknik analisis keuangan : petunjuk praktis untuk mengelola dan mengukur kinerja perusahaan. Jakarta: Penerbit Erlangga.

Hidayat, K., Ompusunggu, A.P., \& Suranto, H. (2016). Pengaruh corporate social responsibility terhadap agresivitas pajak dengan insentif pajak sebagai pemoderasi (Studi pada perusahaan pertambangan yang terdaftar di BEI). Jurnal Ilmiah Akuntansi Fakultas Ekonomi, 2(2), 39-58.

Hoi, C.K., Wu, Q., \& Zhang, H. (2013). Is corporate social responsibility (CSR) associated with tax avoidance? Evidence from irresponsible CSR activities. The Accounting Review, 88 (6), 2025-2059.

Huseynov, F., \& Klamm, B.K. (2012). Tax avoidance, tax management and 
corporate social responsibility. Journal of Corporate Finance, 18(4), 804-827.

Jama'an, 2008. Pengaruh Mekanisme Corporate Governance dan Kualitas Kantor Akuntan Publik terhadap Integritas Informasi Laporan Keuangan (Thesis). Program Studi Magister Sains Akuntansi Universitas Diponegoro, Semarang.

Kuriah, H.L., \& Asyik, N.F. (2016). Pengaruh karakteristik perusahaan dan corporate social responsibility terhadap agresivitas pajak. Jurnal Ilmu dan Riset Akuntansi, 5(3), 1-19.

Kusumo, W.K.R.H., \& Asyik, N. F. (2017). Pengaruh Agresivitas Pajak, Ukuran Perusahaan, Leverage, dan Roa terhadap Corporate Social Responsibility. Jurnal Ilmu dan Riset Akuntansi, 6(12).

Landry, S., Deslandes, M., \& Fortin, A. (2013). Tax aggressiveness, corporate social responsibility, and ownership structure. Journal of Accounting, Ethics and Public Policy, 14(3), 611645.

Lanis, R., \& Richardson, G. (2012). Corporate social responsibility and tax aggressiveness: An empirical analysis. Journal of Accounting and Public Policy, 31(1), 86-108.

Lanis, R., \& Richardson, G. (2013). Corporate social responsibility and tax aggressiveness: A test of legitimacy theory. Accounting, Auditing \& Accountability Journal, 26 (1), 75-100.

Lanis, R., \& Richardson, G. (2015). Is corporate social responsibility performance associated with tax avoidance? Journal of Business Ethics, 127(2), 439-457.

Leuz, C., Nanda, D., \& Wysocki, P.D. (2003). Earnings management and investor protection: an international comparison. Journal of Financial Economics, 69(3), 505-527.

Mackey, A., Mackey, T., \& Barney, J. (2007). Corporate social responsibility and firm performance: investor preferences and corporate strategies. Academy of Management Review, 32 (3), 817-835.

Maesarah, Y., Atikah, S., \& Husnaini, W. (2013). Pengaruh Karakteristik Perusahaan dan Corporate Social Responsibility terhadap Penghindaran Pajak. Paper dipresentasikan pada KRA II (Konferensi Regional Akuntansi).
Maksum, A., \& Kholis, A. (2003). Analisis tentang pentingnya tnaggung jawab dan akuntansi sosial perusahaan (corporate social responsibility): Studi empiris di kota medan. Paper dipresentasikan pada acara Simposium Nasional Akuntansi VI Surabaya.

Maraya, A.D., \& Yendrawati, R. (2016). Pengaruh corporate governance dan corporate social responsibility disclosure terhadap tax avoidance: Studi empiris pada perusahaan tambang dan CPO. Jurnal Akuntansi dan Auditing Indonesia, 20(2), 147159.

Mumtahanah, S.N., \& Septiani, A. (2017). Pengaruh pengungkapan corporate social responsibility terhadap agresivitas pajak dengan moderasi kepemilikan saham oleh keluarga (Studi pada perusahaan pertambangan yang terdaftar di bursa efek indonesia tahun 20132015). Diponegoro Journal of Accounting, 6(4), 1-13.

Muzakki, M.R., \& Darsono. (2015). Pengaruh corporate social responsibility dan capital intensity terhadap penghindaran pajak. Diponegoro Journal of Accounting, 4(3), 1-8.

Napitu, A.T., \& Kurniawan, C.H. (2016). Analisis faktor-faktor yang mempengaruhi agresivitas pajak perusahaan manufaktur di bursa efek indonesia periode 2012-2014. Paper dipresentasikan pada acara Simposium Nasional Akuntansi XIX, Lampung.

Nusantari, N.I., Nuzula, N.F., \& Darono, A. (2015). Pengaruh agresivitas pajak terhadap pengungkapan corporate social responsibility (CSR) (Studi pada perusahaan yang terdaftar dalam indeks SRI KEHATI tahun 2011-2013). Jurnal Administrasi Bisnis-Perpajakan (JAB), 5(2).

Oktaviana, N.E., (2014). Pengaruh agresivitas pajak terhadap corporate social responsibility: untuk menguji teori legitimasi (studi empiris pada perusahaan pertambangan dan properti yang terdaftar di Bursa Efek Indonesia tahun 2009-2012) (Skripsi). Fakultas Ekonomika dan Bianis, Universitas Diponegoro, Semarang.

Peraturan Pemerintah No. 47 tahun 2012. Tanggung jawab sosial dan lingkungan perseroan terbatas. 4 April 2012. Lembaran Negara Republik Indonesia Nomor 5305. Jakarta.

Pradipta, D.A., \& Supriyadi. (2015). 
Pengaruh Corporate Social Responsibility terhadap Perencanaan Agresivitas Pajak (Makhfudloh, Herawati Dan Wulandari)

Pengaruh corporate social

responbility, profitabilitas, leverage, dan komisaris independen terhadap praktik penghindaran pajak. Paper dipresentasikan pada acara Simposium Nasional Akuntansi XVIII, Medan.

Pradnyadari, I.D.A.I., \& Rohman, A. (2015). Pengaruh pengungkapan corporate social responsibility terhadap agresivitas pajak. Diponegoro Journal of Accounting, 4(2), 1-9.

Prasista, P.M., \& Setiawan, E. (2016). Pengaruh profitabilitas dan pengungkapan corporate social responsibility terhadap agresivitas pajak penghasilan wajib pajak badan. EJurnal Akuntansi Universitas Udayana, 17(3), 2120-2144.

Purwanggono, E. A., \& Rohman, A. (2015). Pengaruh corporate social responsibility dan kepemilikan mayoritas terhadap agresivitas pajak (Studi empiris pada perusahaan manufaktur yang terdaftar di bursa efek indonesia tahun 2011-2013). Diponegoro Journal of Accounting, 4 (2), 1-13.

Ratmono, D., \& Sagala, W.M. (2015). Pengungkapan corporate social responsibility (CSR) sebagai sarana legitimasi: dampaknya terhadap tingkat agresivitas pajak. Jurnal Nominal, 4(2).

Rini, D.M., Handajani, L., \& Sasanti, E.E. (2015). Agresivitas pajak pada perusahaan publik indonesia yang melakukan pengungkapan corporate social responsibility. Paper dipresentasikan pada acara Simposium Nasional Akuntansi XVIII, Medan.

Rohmati, W.F. (2013). Analisis pengaruh CSR performance dan CSR reporting terhadap tax aggresiveness pada perusahaan yang terdaftar di BEI (Skripsi). Universitas Indonesia, Jakarta.

Sagala, W.M., \& Ratmono, D. (2015). Analisis pengaruh pengungkapan corporate social responsibility terhadap agresivitas pajak. Diponegoro Journal of Accounting, 4 (3), 1-9.

Sari, D.L., Darlis, E., \& Wiguna, M. (2017). Pengaruh corporate social responsibility, kepemilikan mayoritas dan corporate governance terhadap agresivitas pajak (Studi pada perusahaan manufaktur yang terdaftar di BEI tahun 2011-2014). JOM Fekon, 4(1), 1813-1827.
Sembiring, E.R. (2005). Karakteristik perusahaan dan pengungkapan tanggung jawab sosial: studi empiris pada perusahaan yang tercatat di bursa efek jakarta. MAKSI, 6(1), 69-85.

Septiani, M. (2013). Pengaruh karakteristik perusahaan terhadap corporate social responsibility disclosure dan implikasinya terhadap earning per share (Skripsi). Fakultas Ekonomika dan Bisnis, Universitas Diponegoro, Semarang.

Sugiyono. (2013). Metoda penelitian pendidikan. Bandung : Alfabeta.

Tang, T.Y.H. (2015). Does book-tax conformity deter opportunistic book and tax reporting? An International analysis. European Accounting Review, 24(3), 441-469.

Tjondro, E., Widuri, R., \& Katopo, J. M. (2016). Kualitas corporate social responsibility dan penghindaran pajak dengan kinerja laba sebagai moderator. Jurnal Akuntansi dan Keuangan, 18(2), 105-118.

Toly, A.A., \& Jessica. (2014). Pengaruh pengungkapan corporate social responsibility terhadap agresivitas pajak. Tax \& Accounting Review, 4(1).

Tsakumis, G.T., Curatola, A.P., \& Porcano, T.M. (2007). The relation between national cultural dimensions and tax evasion. Journal of International Accounting, Auditing and Taxation, 16(2), 131-147.

Undang-Undang Republik Indonesia. (2007). Undang-Undang Nomor 40 Tahun 2007 tentang Perseroan Terbatas.

Wahyudi, D. (2016). Analisis empiris pengaruh aktifitas corporate social responsibility (csr) terhadap penghindaran pajak di Indonesia. Proceeding Pertemuan Ilmiah Tahunan (PIT) Nasional ke-2 Ikatan Widyaiswara Indonesia (IWI) Provinsi Banten.

Warsono \& Ardianto, Y. (2015). Pengaruh corporate social responsibility terhadap agresivitas pajak dengan insentif pajak sebagai pemoderasi (Studi pada perusahaan pertambangan di indonesia). Jurnal Manajemen Bisnis Indonesia, 2(2), 236 $-249$.

Watson, L. (2011). Corporate social responsibility and tax aggressiveness: An examination of unrecognized tax benefits. Working Paper. The Pennsylvania State University.

Watson, L. (2015). Corporate social 
JURNAL AKUNTANSI DAN BISNIS Vol. 18, No. 1, Februari 2018: 48-60

responsibility, tax avoidance, and earnings performance. The Journal of the American Taxation Association (JATA), 37(2), 1-21.

Winarsih, R., Prasetyono., \& Kusufi, M.S. (2014). Pengaruh Good Corporate Governance dan Corporate Social Responsibility terhadap Tindakan Pajak Agresif (Studi pada Perusahaan Manufaktur yang Listing di BEI Tahun 2009-2012). Paper dipresentasikan pada acara Simposium Nasional Akuntansi 17 Mataram, Lombok.
Yunistiyani, V., \& Tahar, A. (2017). Corporate social responsibility dan agresivitas pelaporan keuangan terhadap agresivitas pajak dengan good corporate governance sebagai pemoderasi (Studi pada perusahaan manufaktur di bursa efek indonesia). Jurnal Ilmiah Akuntansi, 2(1), 1-31.

Zeng, T. (2016). Corporate social responsibility, tax aggressiveness, and firm market value. Accounting Perspectives, 15(1), 7-30. 